\title{
Estimation and Comparison of Serum Levels of Sodium, Potassium, Calcium and Phosphorus in Different Stages of Chronic Kidney Disease
}

\author{
Poudel B ${ }^{1}$, Mittal A2 , Yadav BK ${ }^{3}$, Sharma $\mathrm{P}^{4}$, Jha B ${ }^{5}$, Raut KB
}

${ }^{1}$ Lecturer, Department of Biochemistry, Manipal College of Medical Sciences, Pokhara, Nepal.

${ }^{2}$ Associate Professor, Department of Biochemistry, Manipal College of Medical Sciences, Pokhara, Nepal.

${ }^{3}$ Assistant Professor, Department of Biochemistry, Institute of Medicine. Kathmandu, Nepal.

${ }^{4}$ M. Sc. Molecular Biology Student, Institute of Biomolecular Reconstruction, SunMoon University, South Korea.

5Professor \& Head, Department of Biochemistry, Institute of Medicine. Kathmandu, Nepal.

${ }^{6}$ Professor, Department of Internal Medicine (Nephrology Unit), Institute of Medicine. Kathmandu, Nepal.

\section{Original Article}

Corresponding Author:

Mr. Bibek Poudel, MSc (Clinical Biochemistry)

Lecturer, Department of Biochemistry,

Manipal College of Medical Sciences, Pokhara, Nepal

E-mail: bibekclb@yahoo.com

\section{Abstract}

\section{Background}

Chronic Kidney Disease (CKD) is a worldwide growing issue and a public health problem. It is associated with significant morbidity and mortality. The prevalence of CKD has been described in several studies. High prevalence of CKD has also reported in the different studies from different part of world. The prevalence of reduced glomerular filtration rate (GFR) in Australia was $11.2 \%$. Singapore, a South-East Asian country, reported a CKD prevalence of $10.1 \%$, while the prevalence of CKD in Japanese general population was reported to be $18.7 \%$. Reduced kidney function is associated with a variety of biochemical abnormalities such as electrolytes. However, the extent of the changes and their magnitude in relation to different stages of CKD is not well defined especially in the early stages of CKD. Thus, the main objective of our study was to assess the variations in the serum levels of sodium, potassium, calcium and phosphorus in different stages of CKD.

\section{Materials and methods}

It was a hospital based cross-sectional study conducted in the Department of Clinical Biochemistry in collaboration with the Department of Internal Medicine (nephrology unit), Kathmandu, Nepal between $1^{\text {st }}$ February, 2008 to $1^{\text {st }}$ January, 2010. CKD was defined as per National Kidney Foundation Guidelines. The variables collected were age, gender, blood pressure, serum level of urea, creatinine, sodium, potassium, calcium, phosphorus, urinary albumin, urinary total protein (UTP), urinary protein creatinine ratio (PCR). The One way ANOVA was used to examine the statistical significant difference between groups. Correlation of different parameters with markers of CKD was done by Pearson's correlation for quantitative data. A p-value of $<0.05$ (two-tailed) was used to establish statistical significance.

\section{Results}

Increased values of systolic and diastolic blood pressure found up to the level of stage IV CKD. However, in stage V CKD a slight decrement of blood pressure from stage IV CKD was seen. With the progression of stages of CKD, sodium levels were found to be decreased $(p<0.001)$. In contrast to that potassium and phosphorus levels were found to be increased with the stages of CKD and $(p<0.001)$. Serum level of calcium was found to be declined with the augment in stages of CKD $(p<0.001)$. Positive and negative correlation of different parameters with kidney damage markers was assessed by Pearson's correlation coefficient. 


\section{Conclusion}

The elevation in serum level of potassium, phosphorus and decrease in serum level of calcium were obvious even among the patients with early stages CKD.

\section{Keywords}

Chronic Kidney Disease, Sodium, Potassium, Calcium Phosphorus.

\section{Background}

Chronic Kidney Disease (CKD) is a worldwide growing issue and a public health problem. It is associated with significant morbidity and mortality ${ }^{1,2}$. The prevalence of CKD has been described in several studies. In the United States, crosssectional analysis of the most recent National Health and Nutrition Examination Surveys (NHANES) showed that the prevalence of CKD increased from $10.0 \%$ in 1988-1994 to $13.1 \%$ in $1999-2004^{2}$. High prevalence of CKD has also reported in the different studies from Europe, Australia, and Asia. The prevalence of reduced GFR in Australia was $11.2 \%{ }^{3}$. Singapore, a South-East Asian country, reported a CKD prevalence of $10.1 \%$, while the prevalence of CKD in Japanese general population was reported to be $18.7 \%{ }^{4,5}$.

Bone disorders associated with CKD comprises of a number of abnormalities of bone metabolism. Bone disorders develop during the course of CKD can be categorized into (a) associated with increased bone turnover and increase parathyroid hormone (PTH) levels including osteitis fibrosa, lesion of secondary hyperparathyroidism (b) decrease bone turnover and decrease or normal PTH level including osteomalacia and adynamic bone disease. The pathophysiological mechanism behind the development of bone disorder through secondary hyperparathyroidism results in abnormal mineral metabolism including declining in kidney function. This leads to reduced phosphorus excretion and consequent phosphorus retention. Elevated serum phosphorus level can directly suppress the 1hydroxylase enzyme and consequently decrease calcitriol production; moreover reduced functional mass of kidney leads to decrease calcitriol production. Decreased calcitriol production causes reduced calcium absorption from the gastrointestinal tract which further contributes to hypocalcemia ${ }^{6}$. Elevated serum phosphorus level reduces calcitriol synthesis and hypocalcaemia jointly stimulate the production of PTH and the proliferation of parathyroid cells which contribute to the development of secondary hyperparathyroidism. High level of PTH stimulates osteoblasts and causes high bone turnover ${ }^{7}$. Low turnover bone disorders include osteomalacia and adynamic bone disorders. Both disorders are due to decrease in bone turn over or remodeling which is associated with the reduced number of osteoclasts and osteoblasts, and decreased osteoblastic activity. An accumulation of unmineralized bone matrix or increased osteoid volume can be found in osteomalacia. Reduced bone volume and mineralization can be found in adynamic bone disease. Bone disorders associated with alteration of calcium and phosphorus levels develop during the course of CKD and are associated with adverse outcomes if patients with eGFR $<60 \mathrm{ml} / \mathrm{min} / 1.73 \mathrm{~m}^{2}$. In this state, patients should be evaluated for bone disorders and disorders of calcium and phosphorus metabolism. Normal kidney retains sodium and for electrical neutrality excretes the potassium in urine. Reduced kidney function and functional mass of kidney causes reduction in sodium retention, and potassium excretion through urine.

Reduced kidney function is associated with a variety of biochemical abnormalities which includes serum concentration of sodium, potassium, calcium and phosphorus $^{8,9}$. However the extent of the changes of these parameters and their magnitude in relation to different stages of CKD is not well defined especially among the person with mild to moderate CKD (i.e. early stages CKD). It urges us to see the level of sodium, potassium, calcium and phosphorus in different stages of CKD. Thus, the main objective of our study was to assess the variations in the serum levels of sodium, potassium, calcium and phosphorus in different stages of CKD.

\section{Material and Methods}

\section{Study design and the participants}

It was a hospital based cross-sectional study conducted in the Department of Clinical Biochemistry in collaboration with the Department of Internal Medicine (nephrology unit), Tribhuvan University Teaching Hospital, Institute of Medicine (TUTH, IOM). Tribhuvan University teaching hospital is a tertiary care hospital in capital city of Nepal and it is a well facilitated and equipped hospital for patients with kidney disease. Hence, this site was chosen for the study.

\section{Data collection}

This study was carried out from $1^{\text {st }}$ February, 2008 to $1^{\text {st }}$ January, 2010. The study population included patients visiting the medical out-patient department (OPD) and nephrology unit of TUTH from different parts of Nepal. A medical history was taken and a physical examination was performed by a physician. After obtaining written consent from the participants, 125 participants over the age of 16 years and below 60 years having CKD were eligible for the measurement of biochemical profile including urea, creatinine, sodium, potassium, calcium, phosphorus and so on. Furthermore, 106 healthy controls i.e. non-CKD were also enrolled. Age, sex, weight, blood pressure were collected from the participants. Participants with haemophilia and recent cancer chemotherapy were excluded from the venipuncture. $5 \mathrm{ml}$ of blood was drawn after an overnight fast (12 -16 hours) by venous puncture and spot urine sample was also collected. After clotting of blood, serum was separated within an hour by centrifugation. Serum was used for biochemical profile. The urine sample was also processed on the same day and 
estimated for urinary albumin, protein and creatinine. Laboratory standard operation procedures were maintained for all laboratory analysis. Internal quality control sera, both normal and pathological were also run for each lot of the test for the validation of the results.

\section{Inclusion criteria}

The participants having age more than 16 years and less than 60 years having CKD were enrolled as a study population. Similarly, the participants having age more than 16 years and less than 60 years without CKD were enrolled as a healthy control group.

\section{Exclusion criteria}

For study cases: The participants of ages less than 16 years and more than 60 years, pregnancy, HIV infection, chronic disease like tuberculosis, COPD, liver disease, endocrine disorder, patients under medication for calcium.

For healthy controls: The participants having age less than 16 years and more than 60 years, pregnancy, HIV infection, chronic disease like malignancy, chain smokers, tuberculosis, COPD, liver disease, endocrine disorder, patients under medication for calcium, diabetes mellitus, hypertension, any medical history of CKD.

\section{Sample size calculation}

In a pilot study of 9 patients with stage I CKD, we found Mean potassium was 4 and $\sigma=0.1=$ standard deviation. For, $95 \%$ confidence interval, $Z=1.96,5 \%$ significance level, $E=0.04=$ Allowable error. Therefore required sample size with $n=\left\{Z^{2} X \sigma^{2}\right\} / E^{2}$ was $24^{10}$.

\section{Outcome variables:}

Serum level of urea (Enzymatic method) ${ }^{11}$, creatinine (modified Jaffe's reaction) $^{12}$, calcium (o-cresolphthaleincomplexone (CPC) $)^{13}$ and phosphorus (precipitate method) ${ }^{14}$ were measured using fully- automated chemistry analyzer, BT 2000, Italy. Serum level of sodium and potassium were measured using flame emission spectrophotometry ${ }^{15}$. Urinary protein was measured in BT 2000 Plus biotechnica instruments - clinical chemistry analyser ${ }^{16}$. Urine albumin was estimated by solid phase, sandwich-format, immunometric assays (NycoCard, U-Albumin, Norway). Colour developed by the conjugate on the membrane is measured by using the colour densitometer (NycoCard READER II, Axis-Shield PoC AC, Norway).

\section{Explanatory variables:}

CKD was defined as either (a) the presence of microalbuminuria (>3.4 $\mathrm{mg}$ albumin $/ \mathrm{mmol}$ creatinine) as a marker of kidney damage or (b) reduced excretory function with an eGFR<60 mL/min/1.73 $\mathrm{m}^{2}$ as a marker of kidney dysfunction or both for more than two months ${ }^{17,18,19 .}$

In spot urine sample albumin was measured quantitatively and adjusted to creatininuria. Then, it was interpreted as albumin creatinine ratio $(A C R) \geq 3.4-33.9 \mathrm{mg}$ albumin $/ \mathrm{mmol}$ creatinine as microalbuminuria ${ }^{19}$.
The formula of Cockcroft and Gault equation ${ }^{20}$ for creatinine clearance $(\mathrm{Ccr})$ in males:

$$
\begin{gathered}
C \mathrm{cr},=[140-\text { age }(\text { in years })] \times \text { weight }(\text { in } \mathrm{kg}) \times 88.4 /[72 \times \\
\text { serum creatinine }(\mu \mathrm{mol} / \mathrm{L})]
\end{gathered}
$$

A comparative equation for women was proposed on the basis of their $15 \%$ lower muscle mass (on average):

$$
\begin{gathered}
C \mathrm{cr}=[140-\text { age }(\text { in years })] \times \text { weight }(\text { in } \mathrm{kg}) \times 88.4 \times 0.85 / \\
{[72 \times \text { serum creatinine }(\mu \mathrm{mol} / \mathrm{L})]}
\end{gathered}
$$

After establishing the CKD, it was further classified into five different stages of CKD as: Stage I CKD (if eGFR is >90 $\mathrm{mL} / \mathrm{min} / 1.73 \mathrm{~m}^{2}$ ), Stage II CKD (if eGFR is between 60 and $<90 \mathrm{~mL} / \mathrm{min} / 1.73 \mathrm{~m}^{2}$ ), Stage III CKD (if eGFR is between 30 and $<60 \mathrm{~mL} / \mathrm{min} / 1.73 \mathrm{~m}^{2}$ ), Stage IV CKD (if eGFR is between 15 and $<30 \mathrm{~mL} / \mathrm{min} / 1.73 \mathrm{~m}^{2}$ ) and Stage $V$ CKD (if eGFR is $\left.<15 \mathrm{~mL} / \mathrm{min} / 1.73 \mathrm{~m}^{2}\right)^{17}$. Apart from these, age, sex, blood pressure and weight were also collected.

\section{Ethical committee approval}

Preceding the study, approval for the study was obtained from the institutional research ethical committee.

\section{Data management and statistical analysis}

The data was analyzed using Excel 2003, R 2.8.0 Statistical Package for the Social Sciences (SPSS) for windows version 16.0 (SPSS Inc; Chicago, IL, USA). Comparison of mean of continuous data between different stages of CKD was tested by one-way ANOVA. Correlation of different parameters with markers of CKD was done by Pearson's correlation for quantitative data. A p-value of $<0.05$ (two-tailed) was used to establish statistical significance ${ }^{21,22}$.

\section{Results}

Participants with ages more than 16 and less than 60 years having CKD were enrolled as a study population. We had enrolled 106 participants as a healthy control (non-CKD) and 125 cases of CKD. In the normal healthy control group, 58 were males and 48 were females. Similarly, in cases, 71 were males and 54 were females. Among the enrolled CKD cases, there were 25 cases of each stage of CKD i.e. from stage I to stage $\mathrm{V}$.

Table 1 shows that the mean difference of age, systolic blood pressure (SBP), urea, creatinine, eGFR, urinary total protein (UTP), urinary protein creatinine ratio (PCR), potassium, calcium and phosphorus among the different stages of CKD. Systolic and diastolic blood pressure was increased up to the level of stage IV CKD. However, in stage $\checkmark$ CKD a slight decrement of blood pressure from stage IV CKD was seen. Serum urea and creatinine levels were found to be increased with the stages of CKD. Similarly, urinary total protein and urinary protein creatinine ratio were found to be increased with the stages of CKD. Furthermore, with the increase in stages of CKD, sodium levels was found to be decreased and it was statistically insignificant. In contrast, potassium and phosphorus levels were found to 
be increased with the stages of CKD and it was statistically significant. Serum level of calcium was found to be decreased with the increase of stages of CKD and it was statistically significant.

Table1: Mean comparison of different characteristics with the stages of CKD

\begin{tabular}{|c|c|c|c|c|c|c|c|}
\hline \multirow{3}{*}{$\begin{array}{l}\text { Different } \\
\text { Paramet } \\
\text { ers }\end{array}$} & \multicolumn{6}{|c|}{ Stages of Chronic Kidney Disease } & \multirow{3}{*}{ p-Value } \\
\hline & $\begin{array}{l}\text { Non- } \\
\text { CKD } \\
n=106\end{array}$ & $\begin{array}{l}\text { Stage- } \\
\text { ICKD } \\
n=25\end{array}$ & \begin{tabular}{|l|} 
Stage-II \\
CKD \\
$n=25$
\end{tabular} & \begin{tabular}{|l|} 
Stage-III \\
CKD \\
$n=25$
\end{tabular} & $\begin{array}{l}\text { Stage-IV } \\
\text { CKD } \\
n=25\end{array}$ & \begin{tabular}{|l|} 
Stage-V \\
CKD \\
$n=25$
\end{tabular} & \\
\hline & $\begin{array}{l}\text { Mean } \\
\pm S D\end{array}$ & $\begin{array}{l}\text { Mean } \\
\pm S D\end{array}$ & $\begin{array}{l}\text { Mean } \\
\pm S D\end{array}$ & $\begin{array}{l}\text { Mean } \\
\pm S D\end{array}$ & $\begin{array}{l}\text { Mean } \\
\pm S D\end{array}$ & $\begin{array}{l}\text { Mean } \\
\pm \text { SD }\end{array}$ & \\
\hline AGE & $\begin{array}{c}41.9 \\
\pm 9.8 \\
(40.09- \\
43.85)\end{array}$ & $\begin{array}{c}37.5 \\
\pm 8.5 \\
(34- \\
41.03)\end{array}$ & $\begin{array}{c}39.8 \\
\pm 9.7 \\
(35.82- \\
43.85)\end{array}$ & $\begin{array}{c}52.64 \\
\pm 9.4 \\
(48.78- \\
56.5)\end{array}$ & $\begin{array}{c}52.08 \pm \\
9.1 \\
(48.32- \\
55.83)\end{array}$ & $\begin{array}{c}53.68 \\
\pm 7.34 \\
(50.65- \\
56.7)\end{array}$ & $0.001+$ \\
\hline SBP & $\begin{array}{c}120.3 \\
\pm 11.02 \\
(118.16- \\
122.41)\end{array}$ & $\begin{array}{c}135.8 \\
\pm 11.6 \\
(131- \\
140.59)\end{array}$ & $\begin{array}{c}135.4 \\
\pm 18.4 \\
(127.76- \\
142.95)\end{array}$ & $\begin{array}{c}148.6 \\
\pm 17.3 \\
(141.46- \\
155.73)\end{array}$ & $\begin{array}{c}162 \\
\pm 21.55 \\
(153.1- \\
170.89)\end{array}$ & $\begin{array}{c}153.4 \\
\pm 22.04 \\
(144.31- \\
162.49)\end{array}$ & $<0.001+$ \\
\hline DBP & $\begin{array}{c}78.3 \\
\pm 8.34 \\
(76.69- \\
79.9)\end{array}$ & $\begin{array}{c}91.4 \\
\pm 6.04 \\
(88.9- \\
93.89)\end{array}$ & $\begin{array}{c}91.2 \\
\pm 10.82 \\
(86.73- \\
95.67)\end{array}$ & $\begin{array}{c}99.5 \\
\pm 7 \\
(96.68- \\
102.51)\end{array}$ & $\begin{array}{c}95 \\
\pm 8.42 \\
(91.52- \\
98.47)\end{array}$ & & $<0.001^{\dagger}$ \\
\hline Urea & $\begin{array}{c}4.6 \\
\pm 0.9 \\
(4.44- \\
4.79)\end{array}$ & $\begin{array}{c}4 . .5 \\
\pm 0.67 \\
(4.22- \\
4.78)\end{array}$ & $\begin{array}{c}4.54 \\
\pm 1 \\
(4.13- \\
4.96)\end{array}$ & $\begin{array}{c}7.45 \\
\pm 1.61 \\
(6.78- \\
8.12)\end{array}$ & $\begin{array}{c}12.17 \\
\pm 3 \\
(10.93- \\
13.41)\end{array}$ & $\begin{array}{c}15.8 \\
\pm 4.2 \\
(14.04- \\
17.51)\end{array}$ & 00 \\
\hline $\begin{array}{c}\text { Creatini } \\
\text { ne }\end{array}$ & $\begin{array}{c}88.6 \\
\pm 14.14 \\
(85.87- \\
91.31)\end{array}$ & $\begin{array}{c}83.24 \\
\pm 13.42 \\
(77.69- \\
88.78)\end{array}$ & $\begin{array}{c}95.44 \\
\pm 22.16 \\
(86.29- \\
104.58)\end{array}$ & $\begin{array}{c}120 \\
\pm 30 \\
(107.59- \\
132.4)\end{array}$ & $\begin{array}{c}160.5 \\
\pm 27.25 \\
(149.27- \\
171.76)\end{array}$ & $\begin{array}{c}329 \\
\pm 49 \\
(308.97- \\
349.42)\end{array}$ & $<0.001^{\dagger}$ \\
\hline eGFR & $\begin{array}{c}85.6 \\
\pm 15.71 \\
(82.52)\end{array}$ & $\begin{array}{c}103.4 \pm 1 \\
2.12 \\
(98.38- \\
108.38)\end{array}$ & $\begin{array}{c}71.64 \\
\pm 7 \\
(68.73- \\
74.55)\end{array}$ & $\begin{array}{c}45.4 \\
\pm 7 \\
(42.48- \\
48.29)\end{array}$ & $\begin{array}{c}27.2 \\
\pm 2.83 \\
(26.05- \\
28.39)\end{array}$ & $\begin{array}{c}12.8 \\
\pm 1.82 \\
(12.07- \\
13.58)\end{array}$ & $<0.00$ \\
\hline UTP & $\begin{array}{c}102.1 \\
\pm 40.01 \\
(94.42- \\
109.83)\end{array}$ & $\begin{array}{c}219.84 \\
\pm 75.5 \\
(188.65- \\
251.02)\end{array}$ & $\begin{array}{c}340.7 \\
\pm 139.61 \\
(260.8- \\
420.63)\end{array}$ & $\begin{array}{c}487.36 \pm \\
601.78 \\
(238.95- \\
735.76)\end{array}$ & $\begin{array}{c}775 \\
\pm 69.57 \\
(746.31 \\
803.76)\end{array}$ & $\begin{array}{c}797.6 \\
\pm 78.1 \\
(765.32- \\
829.79)\end{array}$ & $<0.001^{\dagger}$ \\
\hline PCR & $\begin{array}{c}11.7 \\
\pm 4.1 \\
(9.23- \\
29.47)\end{array}$ & $\begin{array}{c}26.6 \pm 13 . \\
02 \\
(21.22- \\
31.97)\end{array}$ & $\begin{array}{c}48.3 \pm 33 \\
52 \\
(34.53- \\
62.21)\end{array}$ & $\begin{array}{c}106.46 \pm \\
160.82 \\
(40.07- \\
172.84)\end{array}$ & $\begin{array}{c}186.9 \\
\pm 20.81 \\
(178.3- \\
195.48)\end{array}$ & $\begin{array}{c}199.52 \\
\pm 23.27 \\
(189.91- \\
201.91)\end{array}$ & $<0.001^{\dagger}$ \\
\hline $\mathrm{Na}^{+}$ & $\begin{array}{c}138.5 \\
\pm 4.3 \\
(137.8- \\
139.2)\end{array}$ & $\begin{array}{c}140.7 \\
\pm 2.8 \\
(139.6- \\
141.9)\end{array}$ & $\begin{array}{c}142 \\
\pm 4.6 \\
(140.1- \\
143.9)\end{array}$ & $\begin{array}{c}138.3 \pm 3 \\
8 \\
(136.7- \\
139.8)\end{array}$ & $\begin{array}{c}134 \\
\pm 2.66 \\
(132.9- \\
135.09)\end{array}$ & $\begin{array}{c}133.36 \\
\pm 3.31 \\
(131.99- \\
134.7)\end{array}$ & $<0.001^{\dagger}$ \\
\hline $\mathrm{K}^{+}$ & $\begin{array}{c}4.23 \\
\pm 1.06 \\
(4.03- \\
4.44)\end{array}$ & $\begin{array}{c}3.94 \\
\pm 0.3 \\
(3.83- \\
4.04)\end{array}$ & $\begin{array}{c}4.01 \\
\pm 0.3 \\
(3.88- \\
4.13)\end{array}$ & $\begin{array}{c}4.2 \\
\pm 0.4 \\
(3.99- \\
4.38)\end{array}$ & $\begin{array}{c}4.9 \\
\pm 0.3 \\
(4.75- \\
5.07)\end{array}$ & $\begin{array}{c}5.3 \\
\pm 0.4 \\
(5.1-5.5)\end{array}$ & $<0.001^{\dagger}$ \\
\hline$a^{+2}$ & $\begin{array}{c}2.28 \\
\pm 0.21 \\
(2.23- \\
2.32)\end{array}$ & $\begin{array}{c}2.3 \\
\pm 0.2 \\
(2.2- \\
2.38)\end{array}$ & $\begin{array}{c}2.35 \\
\pm 0.16 \\
(2.28- \\
2.41)\end{array}$ & $\begin{array}{c}1.96 \\
\pm 0.16 \\
(1.89- \\
2.02)\end{array}$ & $\begin{array}{c}1.85 \\
\pm 0.23 \\
(1.75- \\
1.95)\end{array}$ & $\begin{array}{c}1.72 \\
\pm 0.2 \\
(1.63- \\
1.8)\end{array}$ & $<0$. \\
\hline $\mathrm{PO}_{4}^{-3}$ & $\begin{array}{c}4.1 \\
\pm 0.4 \\
(4.06- \\
4.24)\end{array}$ & $\begin{array}{c}4.1 \\
\pm 0.3 \\
(3.99- \\
4.24)\end{array}$ & $\begin{array}{c}4.2 \\
\pm 0.5 \\
(3.97- \\
4.43)\end{array}$ & $\begin{array}{c}4.57 \\
\pm 0.6 \\
(4.33- \\
4.8)\end{array}$ & $\begin{array}{c}4.7 \\
\pm 0.6 \\
(4.46- \\
5.01)\end{array}$ & $\begin{array}{c}5.3 \\
\pm 0.3 \\
(5.16- \\
5.42)\end{array}$ & $<0.001^{\dagger}$ \\
\hline
\end{tabular}

Age(yrs), SBP(mmHg), $\mathrm{DBP}(\mathrm{mmHg}), \quad$ Urea $(\mathrm{mmol} / \mathrm{L})$, Creatinine $(\mu \mathrm{mol} / \mathrm{L})$, eGFR $(\mathrm{mL} / \mathrm{min} / 1.73 \mathrm{~m} 2)$, Urinary Total Protein (UTP) $(\mathrm{mg} / \mathrm{L})$, Protein Creatinine Ratio (PCR) $(\mathrm{mg} /$ $\mathrm{mmol}), \mathrm{Na}^{+}(\mathrm{mEq} / \mathrm{L}), \mathrm{K}^{+}(\mathrm{mEq} / \mathrm{L}), \mathrm{Ca}^{+2}(\mathrm{mmol} / \mathrm{L}), \mathrm{PO}_{4}^{-3}$ (mg/dl)

$+p$-Value $<0.001$, statistically significant

$*$ p-Value $<0.05$, statistically significant
Table 2: Pearson's correlation coefficient of eGFR with different Variables

\begin{tabular}{|c|c|c|}
\hline Variables & Pearson's rho & p-Value \\
\hline Age (yrs) & -0.54 & $<0.001 \dagger$ \\
\hline $\mathrm{SBP}(\mathrm{mmHg})$ & -0.576 & $<0.001+$ \\
\hline $\mathrm{DBP}(\mathrm{mmHg})$ & -0.339 & $<0.001+$ \\
\hline Urea $(\mathrm{mmol} / \mathrm{L})$ & -0.782 & $<0.001 \dagger$ \\
\hline Creatinine $(\mu \mathrm{mol} / \mathrm{L})$ & -0.762 & $<0.001+$ \\
\hline UTP (mg/L) & -0.714 & $<0.001+$ \\
\hline PCR $(\mathrm{mg} / \mathrm{mmol})$ & -0.733 & $<0.001 \dagger$ \\
\hline $\mathrm{Na}^{+}(\mathrm{mEq} / \mathrm{L})$ & 0.470 & $<0.001^{\dagger}$ \\
\hline $\mathrm{K}^{+}(\mathrm{mEq} / \mathrm{L})$ & -0.361 & $<0.001+$ \\
\hline $\mathrm{Ca}^{+2}(\mathrm{mmol} / \mathrm{L})$ & 0.667 & $<0.001 \dagger$ \\
\hline $\mathrm{PO}_{4}^{-3}(\mathrm{mg} / \mathrm{dl})$ & -0.524 & $<0.001 \dagger$ \\
\hline
\end{tabular}

$+p$-Value $<0.001$, statistically significant

* p-Value $<0.05$, statistically significant

Table 2 shows the Pearson's correlation of eGFR with different parameter including sodium and calcium. Negative Pearson's correlation coefficient value indicate the level of Age, SBP,DBP, potassium, phosphorus, Urea, Creatinine, eGFR , Urinary Total Protein , Protein Creatinine Ratio, $\mathrm{K}^{+}$, $\mathrm{PO}_{4}^{-3}$ increases with the decline of GFR and positive Pearson's correlation coefficient value indicate the level of $\mathrm{Na}^{+}, \mathrm{Ca}^{+2}$ parameter decreases with the decline of GFR.

Table 3: Pearson's correlation coefficient of urinary ACR with different Variables

\begin{tabular}{|l|c|c|}
\hline Variables & Pearson's rho & p-Value \\
\hline Age $(\mathrm{yrs})$ & 0.459 & $<0.001^{\dagger}$ \\
$\mathrm{SBP}(\mathrm{mmHg})$ & 0.656 & $<0.001^{\dagger}$ \\
$\mathrm{DBP}(\mathrm{mmHg})$ & 0.378 & $<0.001^{\dagger}$ \\
\hline Urea $(\mathrm{mmol} / \mathrm{L})$ & 0.843 & $<0.001^{\dagger}$ \\
Creatinine ( $\mu \mathrm{mol} / \mathrm{L})$ & 0.813 & $<0.001^{\dagger}$ \\
\hline $\mathrm{UTP}(\mathrm{mg} / \mathrm{L})$ & 0.828 & $<0.001^{\dagger}$ \\
\hline $\mathrm{PCR}(\mathrm{mg} / \mathrm{mmol})$ & 0.833 & $<0.001^{\dagger}$ \\
$\mathrm{Na}{ }^{+}(\mathrm{mEq} / \mathrm{L})$ & -0.492 & $<0.001^{\dagger}$ \\
$\mathrm{K}^{+}(\mathrm{mEq} / \mathrm{L})$ & 0.416 & $<0.001^{\dagger}$ \\
$\mathrm{Ca}^{+2}(\mathrm{mmol} / \mathrm{L})$ & -0.683 & $<0.001^{\dagger}$ \\
$\mathrm{PO}_{4}^{-3}(\mathrm{mg} / \mathrm{dl})$ & 0.553 & $<0.001^{\dagger}$ \\
\hline
\end{tabular}

$+p$-Value $<0.001$, statistically significant

* p-Value $<0.05$, statistically significant

Table 3 shows the Pearson's correlation of urinary albumin creatinine ratio (ACR) with different parameter including sodium and phosphorus. Positive Pearson's correlation coefficient value indicate the level of age, SBP, DBP, potassium, calcium, urea, creatinine, protein creatinine ratio, $\mathrm{Na}^{+}$increases with the increases level of ACR and negative Pearson's correlation coefficient value indicate the level of urinary total protein, $\mathrm{K}^{+}, \mathrm{Ca}^{+2}, \mathrm{PO}_{4}^{-3}$ decreases with the increases of ACR. Parameters at the level of $p$-value $<0.05$ were taken as a statistically significant. 
Table 4: Significance of variables in different stages of CKD when compared to controls

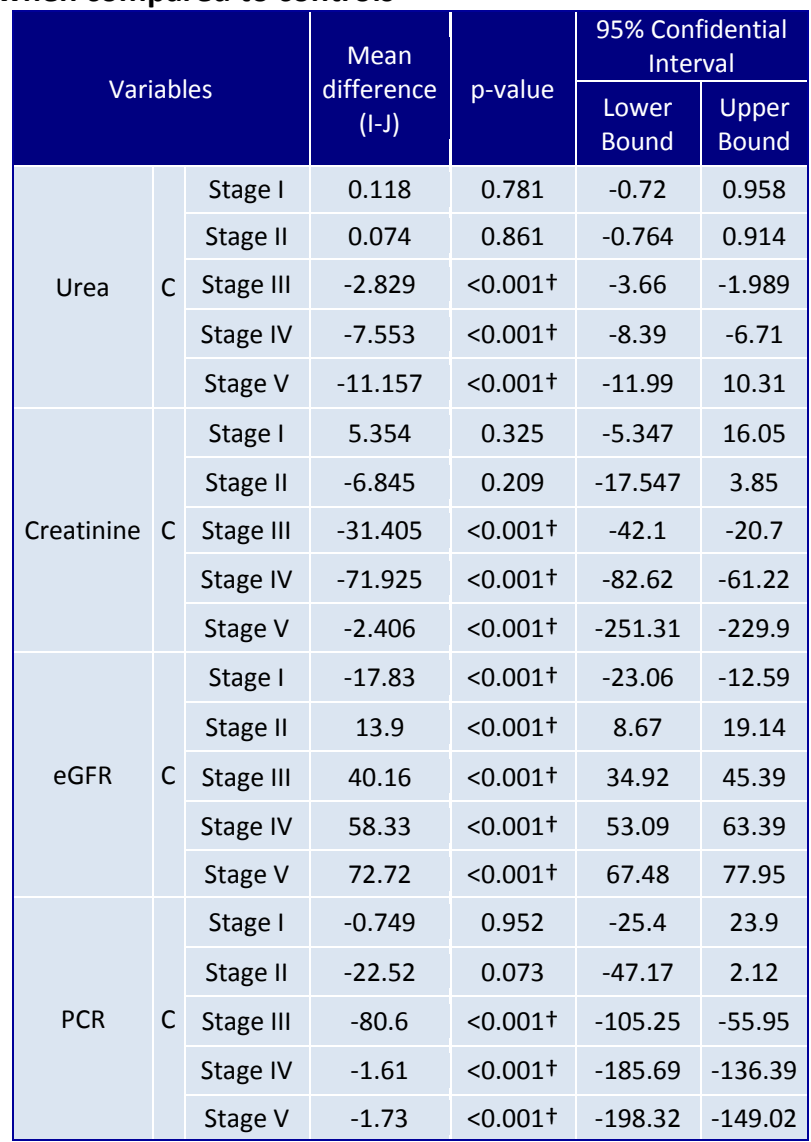

† $\mathrm{p}$-Value $<0.001$, statistically significant, C- Controls

Table 5: Significance of variables in different stages of CKD when compared to controls

\begin{tabular}{|c|c|c|c|c|c|c|}
\hline \multirow{2}{*}{\multicolumn{3}{|c|}{ Variables }} & \multirow{3}{*}{$\begin{array}{c}\begin{array}{c}\text { Mean } \\
\text { difference } \\
(I-J)\end{array} \\
2.48\end{array}$} & \multirow{3}{*}{$\begin{array}{l}\text { p-value } \\
\text { 0.014* }\end{array}$} & \multicolumn{2}{|c|}{ 95\% Confidential } \\
\hline & & & & & \multirow{2}{*}{$\begin{array}{c}\text { Lower } \\
\text { Bound } \\
0.499\end{array}$} & \multirow{2}{*}{$\begin{array}{c}\text { Upper } \\
\text { Bound } \\
4.46\end{array}$} \\
\hline \multirow{5}{*}{$\mathrm{Na}+$} & \multirow{5}{*}{ C } & Stage I & & & & \\
\hline & & Stage II & -3.471 & $<0.001+$ & -5.02 & -1.91 \\
\hline & & Stage III & 0.248 & 0.754 & -1.3 & 1.8 \\
\hline & & Stage IV & 4.528 & $<0.001+$ & 2.97 & 6.08 \\
\hline & & Stage V & 5.168 & $<0.001 \dagger$ & 3.61 & 6.72 \\
\hline \multirow{5}{*}{$\mathrm{K}+$} & \multirow{5}{*}{$\mathrm{C}$} & Stage I & 0.296 & 0.088 & -0.04 & 0.63 \\
\hline & & Stage II & 0.224 & 0.196 & -0.11 & 0.56 \\
\hline & & Stage III & 0.044 & 0.796 & -0.29 & 0.38 \\
\hline & & Stage IV & -0.675 & $<0.001 \dagger$ & -1.01 & -0.33 \\
\hline & & Stage V & -1.08 & $<0.001+$ & 1.42 & -0.74 \\
\hline \multirow{5}{*}{$\mathrm{Ca}^{+2}$} & \multirow{5}{*}{ C } & Stage I & -0.019 & 0.661 & -0.108 & 0.069 \\
\hline & & Stage II & -0.069 & 0.124 & -0.158 & 0.019 \\
\hline & & Stage III & 0.32 & $<0.001 \dagger$ & 0.231 & 0.409 \\
\hline & & Stage IV & 0.424 & $<0.001+$ & 0.335 & 0.513 \\
\hline & & Stage V & 0.56 & $<0.001+$ & 0.471 & 0.649 \\
\hline \multirow{5}{*}{$\mathrm{PO}_{4}{ }^{-3}$} & \multirow{5}{*}{ C } & Stage I & 0.039 & 0.775 & -0.182 & 0.244 \\
\hline & & Stage II & -0.053 & 0.624 & -0.266 & 0.16 \\
\hline & & Stage III & -0.421 & $<0.001 \dagger$ & -0.634 & -0.207 \\
\hline & & Stage IV & -0.589 & $<0.001 \dagger$ & -0.802 & -0.375 \\
\hline & & Stage V & -1.14 & $<0.001+$ & -1.354 & -0.927 \\
\hline
\end{tabular}

† $\mathrm{p}$-Value $<0.001$, statistically significant, C- Controls

$*$ p-Value $<0.05$, statistically significant
Tables 4 and 5 depicts comparison of different variables between the control group and different stages of CKD. Serum level of sodium, potassium, calcium and phosphorus were significantly different in control group and late stages of CKD. However, difference in serum level of sodium, potassium, calcium and phosphorus were statistically insignificant in control group and early stages of CKD.

\section{Discussion \\ Prevalence of CKD}

CKD is a worldwide public health problem. In the US, 9.6\% of non-institutionalized adults are evaluated to have $\mathrm{CKD}^{23,24}$. In Italy, approximate prevalence for stage 3 to 5 CKD is around 4 million $^{25}$. Several studies have been reported from different part of the world including Asia regarding the level of sodium, potassium, calcium and phosphorus (electrolyte and bone metabolism) at different stages of $\operatorname{CKD}^{6,9,26}$. However, much less information is available on serum level of sodium, potassium, calcium and phosphorus from developing regions of the South East Asia. The CKD prevalence in Singapore was reported as $10.1 \%$ and in general population of Japan was found to be $18.7 \%{ }^{27}$ ${ }^{28}$. To the best of our knowledge, this is the first study conducted in Nepal to quantify the relationship of the serum level of sodium, potassium, calcium and phosphorus between the stages of CKD severity. Our results are therefore broadly generalized among the stages of CKD. Since we defined the CKD as per National Kidney Foundation (NKF) guidelines by using kidney dysfunction and kidney damage as a marker; we found that different metabolic abnormalities of CKD were apparent at the different level of renal function and kidney damage.

\section{CKD and Age}

The mean value of age of participants was found to be increased with the stages of CKD. eGFR also decreases with the age. Our present study illustrates that there was significant difference between cases and controls. The mean age for controls was $41.9 \pm 10.1$ yrs and it concurred with the findings of Li ZY et $\mathrm{al}^{29}$.

\section{CKD and Blood Pressure}

Our present study illustrates that there was no significant differences between cases and controls at the various stages of CKD. Systolic blood pressure increases up to the level of stage IV CKD. In stage V CKD, It was comparatively less than stage IV CKD ${ }^{30}$.

\section{CKD and biochemical renal profile}

Serum urea, creatinine, UTP, urinary PCR and eGFR are parts of the renal biochemical profile. Serum level of urea and creatinine was found to increase gradually with the stages of CKD. Similarly, UTP and PCR were also found to gradually increase with progressing stages of CKD. Since the functional mass of kidney decreases in CKD, eGFR also decreased with the stages ${ }^{30,31}$.

\section{Sodium and Potassium levels in CKD}

In our study, with progression of CKD from mild to severe, 
serum potassium levels were found to increase and the elevation was statistically significant. Though the serum level of potassium in mild to moderate form of CKD is physiological unclear, the association between increased serum potassium level with reduced renal function is clear. With the progression of CKD stages, various homeostatic compensatory mechanisms may be operating. Among them, the important mechanism is hormonal changes. For example, aldosterone cannot act in kidney to promote urinary potassium excretion due to decrease functional mass of kidney in $C K D^{32}$. Our study also showed that the mean level of sodium in different stages of CKD was statistically significant. In earlier stages of CKD, the level of sodium was not decreased below the clinical reference range and level of potassium was not increased above the clinical reference range. However, with the progression of CKD from stage III to stage $\mathrm{V}$, hyponatremia and hyperkalemia occurred. The statistically significant difference in serum potassium levels between different stages of CKD might be due to size of the reference range (3.5 to $5.0 \mathrm{mEq} / \mathrm{L}$ ) which represents a $33 \%$ change in concentration, whereas for sodium, the reference range (135 to $145 \mathrm{mEq} / \mathrm{L}$ ) extend over only a 7\% change in concentration $^{33}$.

\section{Phosphorus levels in CKD}

The slight increase in mean value of phosphorus level in study cases with mild to moderate CKD suggests that increase serum phosphorus may stimulate the parathyroid activity at the level of mild to moderate kidney dysfunction ${ }^{34}$. However, the mean phosphorus level was found to be within normal reference range. If there is stimulation of parathyroid activity at the level of mild to moderate kidney dysfunction, the early increment of serum phosphorus level, which is still within the expected range, will not be accompanied by decreased calcium level. Furthermore, increased serum phosphorus level with mild to moderate CKD was found to be independent with diet and duration of fasting period. The increase of serum phosphorus level even above the upper reference range from moderate to severe CKD is due to the secondary hyperparathyroidism, inability of kidney to excrete of phosphorus through urine which was found to be accompanied with decrease level of serum calcium ${ }^{6,26}$.

\section{Calcium levels in CKD}

In this study we found that serum calcium level was not decreased in mild to moderate form of CKD. However, the serum level of calcium was found to be decreased from moderate to severe form of kidney dysfunction. The finding of Pitts et al also concurs with our study in which decreased serum calcium level was apparent ${ }^{34}$. Moreover, our finding was also compatible with the findings of Wilson et $\mathrm{al}^{35}$ and Llach et $\mathrm{al}^{36}$. The biochemical basis of hypocalcaemia with progression of kidney dysfunction includes decrease kidney function leads to reduced excretion of phosphorus through urine and consequent phosphorus retention. Elevated serum levels of phosphorus directly suppresses the synthesis of calcitriol in kidney ${ }^{34,37,38}$. Decreased functional mass of kidney in CKD leads to reduced calcitriol production. The decreased calcitriol production causes reduced calcium absorption from kidney tubules and intestine.

\section{Conclusion}

Elevation in the serum levels of potassium and phosphorus were apparent even in the mild to moderate form of CKD. Calcium level was also significantly decreased with the progressing stages of CKD. However, decreasing level of sodium was not statistically significant. Thus, we conclude that estimation of serum level of sodium, potassium and phosphorus even in the early stage CKD is recommended to assess the electrolyte and bone metabolism.

\section{What this study adds}

In a regular clinical practice, estimation of serum electrolyte levels are done only in case of severe form of CKD (i.e. late stages of CKD) and End Stage Renal Disease (ESRD). More attention has been given only to cure severe forms of CKD instead of trying to prevent the early stages of CKD. Alteration of electrolytes in late stages of CKD is obvious. However, as we have reported in this study, elevation of potassium and phosphorus and decrement levels of calcium even in the mild to moderate form of CKD.

\section{Future scope of study}

Further study can be done with a comprehensive approach on the basis of different levels of mechanism. Causal mechanism for alteration in serum electrolyte level will support the prevention and management of electrolyte alteration in CKD.

\section{Conflict of Interests}

The authors do not have any conflict of interest arising from the study.

\section{Acknowledgments}

The authors are also thankful to Prof. Dr. KB Raut, Department of Internal Medicine (Nephrology Unit), Kathmandu, Nepal; Prof. and Head Bharat Jha, Department of Biochemistry, IOM, TUTH, Kathmandu, Nepal and all the staff of Department of Biochemistry, IOM, TUTH, Kathmandu, Nepal.

\section{Authors' contributions}

BP did concepts and design, literature review, clinical studies, laboratory studies, data collection, data analysis, manuscript editing, review and preparation, manuscript editing and manuscript review. AM analyzed the data and manuscript designed with BP. BKY designed the study, interpreted the data, drafted the manuscript, and revised it with BP. BJ did concept design, literature review and manuscript preparation with BP. KBR designed concept, manuscript editing and review with $\mathrm{BP}$. 


\section{References}

1. U.S. Renal Data System, USRDS 2007 Annual Data Report: Atlas of End-Stage Renal Disease in the United States, National Institutes of Health, National Institute of Diabetes and Digestive and Kidney Diseases, Bethesda, MD, 2007. [online] 2008 [ cited 2011 Nov 13]. Available from: URL: http://www.usrds.org/atlas07.aspx.

2. Coresh J, Selvin E, Stevens LA, Manzi J, Kusek JW, Eggers $P$, Van Lente $F$ and Levey AS. Prevalence of Chronic Kidney Disease in the United States. JAMA 2007; 298(17):2038-47.

3. Chadban SJ, Briganti E, Kerr PG, Dunstan DW, Welborn TA, Zimmet PZ and Atkins RC. Prevalence of Kidney Damage in Australian Adults: The AusDiab Kidney Study. J Am SocNephrol 2003 (suppl); 14:131-8.

4. Imai E, Horio $\mathrm{M}$, Iseki $\mathrm{K}$, Yamagata $\mathrm{K}$, Watanabe $\mathrm{T}$, Hara S, Ura $N$, Kiyohara $Y$ and Hirakata $H$. Prevalence of chronic kidney disease (CKD) in the Japanese general population predicted by the MDRD equation modified by a Japanese coefficient. ClinExpNephrol 2007; 11:156-63.

5. Ramirez SPB, Mcclellan W, Port FK and Hsu SH: Risks factors for proteinuria in a large, multiracial southeast Asian population. J Am SocNephrol 2002; 13:1907-17.

6. Levin A, Bakris GL, Molitch M. Prevalence of abnormal serum vitamin $\mathrm{D}, \mathrm{PTH}$, calcium, and phosphorus in patients with chronic kidney disease: Results of the study to evaluate early kidney disease. Kidney Int 2007; 71: 31-8.

7. De Boer IH, Gorodetskaya I, Young B, Hsu CY, Chertow GM. The severity of secondary hyperparathyroidism in chronic renal insufficiency is GFR-dependent, racedependent, and associated with cardiovascular disease. J. Am. Soc. Nephrol 2002; 13:2762-9.

8. Hsu CY, Chertow GM. Chronic renal confusion: insufficiency, failure, dysfunction, or diseases. Am J Kidney Dis 2000; 36:415-8.

9. Hakim R.M. Lazarus JM. Biochemical parameters in chronic ranal failure. Am J Kidney Dis 1988; 11: 238-47.

10. Sathian B, Sreedharan J, Baboo NS, Sharan K, Abhilash E $S$, Rajesh E. Relevance of Sample Size Determination in Medical Research. Nepal Journal of Epidemiology 2010; 1(1): 4-10.

11. Taylor AJ, Vadgama P. Analytical reviews in clinical biochemistry:the estimation of urea. Ann ClinBiochem 1992; 29:245-64.

12. Fabiny DL, Ertingshausen G. Automated reaction-rate method for determination of serum creatinine with the Centrifichem. ClinChem 1971; 17:696-700.

13. Lorentz K. Improved determination of serum calcium with 2-cresolphthalein complexone.ClinChimActa 1982; 126:327-34.

14. Wentz PW, Savory J, Cross RE. Improved method for measurement of inorganic phosphate in serum with a centrifugal analyzer. clinchem 1976; 22:257-60.

15. Evenson ME. Spectrophotometric technique. In: Burtis CA, Ashwood ER, eds. Tietz textbook of clinical chemistry, 3rd ed.Philadelphia:WB Saunders Co, 1999: 75-93.

16. Ginsb.erg JM, Chang BS, Matarese RA, Garella S. Use of single voided urine samples to estimate quantitative proteinuria. N Engl J Med 1983; 309(25):1543-6.

17. National Kidney Foundation: K/DOQI clinical practice guidelines for chronic kidney disease: Evaluation, classification, and stratification. Kidney Disease Outcome Quality Initiative. Am J Kidney Dis 2002(suppl 1); 39:1-266.

18. Levey AS, Eckardt KU, Tsukamoto Y. Definition and classification of chronic kidney disease: A position statement from Kidney Disease: Improving Global Outcomes (KDIGO). Kidney Int 2005; 67:2089-100.

19. Pruijm MT, Madeleine G, Riesen WF, Burnier M, Bovet $P$. Prevalence of microalbuminuria in the general population of Seychelles and strong association with diabetes and hypertension independent of renal markers. J Hypertens. 2008;26(5):871-7.

20. Cockcroft DW, Gault MH. Prediction of creatinine clearance from serum creatinine. Nephron 1976; 16:31-41.

21. Sathian B. Reporting dichotomous data using Logistic Regression in Medical Research: The scenario in developing countries. Nepal Journal of Epidemiology 2011;1(4):111113.

22. Sathian B. Methodological Rigors in the Medical Journals from Developing Countries: Asian Scenario. Nepal Journal of Epidemiology 2011; 1(5): 141-43.

23. Coresh J, Byrd-Holt D, Astor BC et al. Chronic kidney disease awareness, prevalence, and trends among US adults, 1999 to 2000. J Am SocNephrol 2005; 16: 180-8.

24. Stevens LA, Coresh J, Greene T, Levey AS. Assessing kidney function -measured and estimated glomerular filtration rate. N Engl J Med 2006; 354: 2473-83.

25. Bellizzi V. Prevalence of chronic kidney disease. G ItalNefrol. 2008;25 Suppl 42:S3-7.

26. Block GA, Klassen PS, Lazarus JM, Ofsthun N, Lowrie EG, Chertow GM. Mineral metabolism, mortality, and morbidity in maintenance hemodialysis. J. Am. Soc. Nephrol 2004; 15: 2208-18.

27. Imai $E$, Horio $M$, Iseki $K$, Yamagata $K$, watanabe $T$, Hara S, Ura N, Kiyohara Y, Hirakata H: Prevalence of chronic kidney disease (CKD) in the Japanese general population predicted by the MDRD equation modified by a Japanese coefficient. ClinExpNephrol 2007; 11:156-63.

28. Ramirez SPB, Mcclellan W, Port FK, Hsu SH: Risks factors for proteinuria in a large, multiracial southeast Asian population. J Am SocNephrol 2002; 13:1907-17.

29. Li ZY, Xu GB, Xia TA, Wang HY. Prevalence of chronic kidney disease in a middle and old-aged population of 
Beijing. Clin Chim Acta 2006; 366:209-15.

30. Ridao N, Luño J, García de Vinuesa S, Gómez F, Tejedor A, Valderrábano F. Prevalence of hypertension in renal disease. Nephrol Dial Transplant. 2001; 16 Suppl 1:70-3.

31. Mittal A, Sathian B, Kumar A, Chandrasekharan N, Sunka A. Diabetes Mellitus a Potential Risk Factor for Renal Disease among Nepalese: A Hospital Based Case Control Study. Nepal Journal of Epidemiology 2010; 1(1): 22-5.

32. Friis T, Hahnemann S, weeke E. Serum Calcium and Phosphorous in uraemia during administration of sodium phytates and almunium hydroxide. Acta Med Scand 1968; 183: 497-505.

33. Pesce AJ, Kaplan LA. Methods in Clinical Chemistry. Second edition. The C. V. Mosby Company. 1987: 86-7.

34. Pitts TO, Piraino BH, Mitro R et al. Hyperparathyroidism and 1,25-dihyroxyvitamin $D$ deficiency in mild, moderate and severe renal failure. J ClinEndocrinolMetab 1988; 67: 876-81.

35. Wilson L, Felsenfeld A, Drezner MK, Llach F. Altered divalent ion metabolism in early ranal failure: role of 1,25 (OH)2D. Kidney Int 1985; 27:565-73.

36. Llach F, Massry SG. On the mechanism of secondary hyperparathyroidism in moderate renal insufficiency. J ClinEndocrinolMetab 1985; 61:601-6.

37. Rix M, Andreassen $\mathrm{H}$, Eskildsen P. Bone mineral density and biochemical markers of bone turnover in patients with predialysis chronic renal failure. Kidney Int 1999; 56: 108493.

38. Martinez I, Saracho R, Montenegro J, Llach F. The importance of dietary calcium and phosphorous in the secondary hyperparathyroidism of patients with early renal failure. Am J Kidney Dis 1997; 29(4):496-502.

\begin{tabular}{|l|l|}
\hline \multicolumn{2}{|c|}{ Article Information } \\
\hline \multicolumn{2}{|c|}{ Article history } \\
\hline Received & 1 November 2011 \\
\hline Received in revised form & 30 November 2011 \\
\hline Accepted & 10 December 2011 \\
\hline
\end{tabular}

